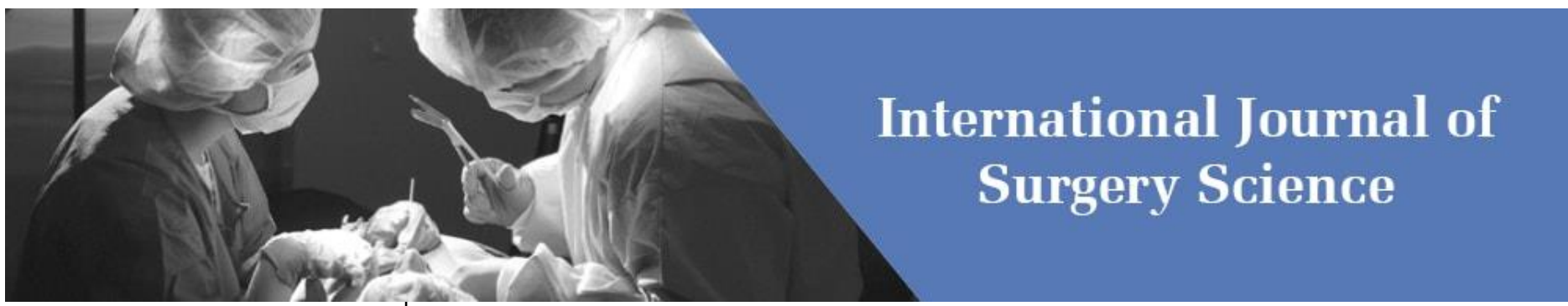

E-ISSN: 2616-3470

P-ISSN: 2616-3462

(C) Surgery Science

www.surgeryscience.com

$2022 ; 6(1)$ : 165-167

Received: 22-11-2021

Accepted: 24-12-2021

Dr. Selvakumarkothandapani M.S., Associate Professor, Department of General Surgery, Srivenkateshwaraa Medical College Hospital and Research Centre,

Ariyur, Puducherry, Tamil Nadu, India

Dr. Bhaskara Rao Bezewada M.S., Assistant Professor,

Department of General Surgery, Melmaruvathur Adhiparasakhthi Institute of Medical Sciences, Melmaruvathur, Tamil Nadu, India

Dr. Muniappan Kaveri

M.S., Professor, Department of

General Surgery,

Srivenkateshwaraa Medical College Hospital and Research Centre, Ariyur, Puducherry, Tamil Nadu, India

Dr. Sugumaran Kandasamy M.S., Associate Professor Department of General Surgery, Srivenkateshwaraa Medical College Hospital and Research Centre, Ariyur, Puducherry, Tamil Nadu, India

Corresponding Author: Dr. Selvakumarkothandapani M.S., Associate Professor, Department of General Surgery, Srivenkateshwaraa Medical College Hospital and Research Centre, Ariyur, Puducherry, Tamil Nadu, India

\section{Efficiency of topical phenytoin in diabetic foot ulcer care: A randomized control trial}

\author{
Dr. Selvakumarkothandapani, Dr. Bhaskara Rao Bezewada, \\ Dr. Muniappan Kaveri and Dr. Sugumaran Kandasamy
}

DOI: $\underline{\text { https://doi.org/10.33545/surgery.2022.v6.i1c.846 }}$

\section{Abstract}

Aim: To study the efficiency of topical phenytoin on healing in diabetic foot ulcer grades 1 and 2 .

Methods: Totally, 60 patients in each group with diabetic foot ulcers of more than 4 weeks duration without any co-morbid conditions and ulcers belonging to Grade 1 and 2 as per Meggitt - Wagner's diabetic foot ulcers were inducted into the study. The whole sample population was divided into two equal and comparable groups based on willingness for undergoing topical phenytoin therapy for the wound. Those who were not willing were subjected to conventional wound care, forming the control group. Antibiotics are given to both groups as per culture reports.

Results: In the study group, 13 patients had granulation tissue at 14 days of less than $75 \%$, and 17 patients had granulation tissue at 14 days of greater than $75 \%$. In the control group mean value of the size of the ulcer initially is $8.76 \mathrm{~cm}$ and in 7 days is $7.12 \mathrm{~cm}$ and in 14 days is $5.86 \mathrm{~cm}$. In the study group mean value of the size of the ulcer initially is $9.03 \mathrm{~cm}$ and in 7 days is $5.63 \mathrm{~cm}$ and in 14days is $3.3 \mathrm{~cm}$.

Conclusion: Phenytoin enhances wound healing via the following mechanisms: stimulation of fibroblast proliferation, enhancement of granulation tissue development, and inhibition of collagenase activity.

Keywords: diabetic foot ulcer, granulation tissue, topical phenytoin, conventional dressings

\section{Introduction}

Management of the diabetic foot requires a multisystem approach, which includes the nervous, vascular, skeletal, immune, and integumentary systems. Phenytoin has been used by many workers because of its positive effects in ulcer healing, such as increase in the proliferation of fibroblasts and deposition of collagen, neovascularization, enhanced granulation tissue formation, decrease in the action of collagenase and bacterial contamination

\section{Aim}

To study the efficiency of topical phenytoin on healing in diabetic foot ulcer grades 1 and 2 .

\section{Materials and Methods}

This randomized controlled study was done in the Department of Surgery Sri Venkateshwaraa Medical College Hospital and Research Centre Ariyur, Puducherry from January 2019 to June 2020. Inclusion criteria:Age group 25-75, both male and female, consent for inclusion in the study, patients with chronic ulcers with diabetes mellitus, wound size <5\% TBSA. Exclusion criteria: Diabetic foot ulcer with Grades III, IV, V according to Meggitt's-Wagner clinical classification and diabetic ulcers with ischaemic changes, tropic ulcers caused by neuropathy, multiple sclerosis, varicose ulcers, and Marjolin's ulcers were excluded. Presence of osteomyelitis, patient on steroids, other comorbid conditions like renal failure, generalised debility which adversely affects wound healing. Patients with allergies to phenytoin.

60 patients in each group with diabetic foot ulcers of more than 4 weeks duration without any co-morbid conditions and ulcers belonging to Grade 1 and 2 as per Meggitt - Wagner's diabetic foot ulcers were inducted into the study. The whole sample population was divided into two equal and comparable groups based on willingness for undergoing topical phenytoin therapy for the wound. Those who were not willing were subjected to conventional wound care, forming the control group. Antibiotics are given to both groups as per culture reports. Daily monitoring of blood sugar was done, appropriate treatments were given. In the well cleaned and debrided wounds, the surface area of the wound is measured on days 7 and 14 using tissue paper mapping. The proper wound care and phenytoin powder application are carried out daily. 
All the measurements were carried on by a single examiner for all the participants. When they were identical, the readings were recorded. If they were not, the average was recorded. Both the groups will undergo dressings twice a day. Patients in both groups followed upto 14 days. The wound is assessed in terms of Rate of granulation tissue formation, reduction in wound surface area, duration of hospital stay (at the end of 14days)

\section{Results}

In this study, 60 cases with DFU grades 1 and 2 were divided into 2 groups, case group underwent topical phenytoin and conventional wound care, forming the control group. In the control group, 18 patients and the study group, 16 patients had a duration of diabetes between 11-20 years. In the control group, 20 patients had traumatic onset, in the study group, 18 patients had a traumatic onset of diabetic foot ulcer. The mean value of fasting blood glucose in the control group is $221 \mathrm{mg} / \mathrm{dl}$ and in the study group is $218 \mathrm{mg} / \mathrm{dl}$.

The mean value of postprandial blood glucose level in the control group is $281 \mathrm{mg} / \mathrm{dl}$ and in the study group is $272 \mathrm{mg} / \mathrm{dl}$. In the study group initially, 8 patients had ulcer size less than 5 $\mathrm{cm}, 13$ patients between $6-10 \mathrm{~cm}, 9$ patients between $11-20 \mathrm{~cm}$. In the study group, 13 patients had granulation tissue at 14 days of less than $75 \%$, and 17 patients had granulation tissue at 14 days of greater than $75 \%$. In the control group mean value of the size of the ulcer initially is $8.76 \mathrm{~cm}$ and in 7 days is $7.12 \mathrm{~cm}$ and in 14 days is $5.86 \mathrm{~cm}$. In the study group mean value of the size of the ulcer initially is $9.03 \mathrm{~cm}$ and in 7 days is $5.63 \mathrm{~cm}$ and in 14days is $3.3 \mathrm{~cm}$. In the control group mean value of the duration of hospital stay is 24.66 days and in the study group is 17.4 days.

Table 1: Distribution of patient's characteristics

\begin{tabular}{|c|c|c|c|}
\hline \multicolumn{2}{|c|}{ Patient characteristics } & Control group & Study group \\
\hline \multirow{4}{*}{ Age group } & $<30$ & 1 & 0 \\
\cline { 2 - 4 } & $31-40$ & 3 & 4 \\
\cline { 2 - 4 } & $41-50$ & 12 & 9 \\
\cline { 2 - 4 } & $51-60$ & 10 & 11 \\
\cline { 2 - 4 } & $>61$ & 4 & 6 \\
\hline \multirow{4}{*}{ Gender } & Male & 25 & 27 \\
\cline { 2 - 4 } & Female & 5 & 3 \\
\hline \multirow{4}{*}{ Duration of Diabetes } & $<5$ & 2 & 4 \\
\cline { 2 - 4 } & $6-10$ & 9 & 16 \\
\cline { 2 - 4 } & $11-20$ & 18 & 1 \\
\cline { 2 - 4 } & $>20$ & 1 & \\
\hline
\end{tabular}

Table 2: Distribution of Wound characteristics

\begin{tabular}{|c|c|c|c|}
\hline \multicolumn{2}{|c|}{ Wound characteristics } & Control group & Study group \\
\hline \multirow{2}{*}{ Type of Onset } & Traumatic & 20 & 18 \\
\cline { 2 - 4 } & Spontaneous & 10 & 12 \\
\hline \multirow{2}{*}{ Site of Ulcer } & Plantar & 20 & 22 \\
\cline { 2 - 4 } & Dorsum & 10 & 8 \\
\hline
\end{tabular}

Table 3: Comparison of presence of granulation tissue

\begin{tabular}{|c|c|c|c|c|c|c|}
\hline Presence of Granulation tissue & No granulation present & $\mathbf{2 5 \%}$ of wound filled & $\mathbf{2 5 - 7 4 \%}$ of wound filled & $\mathbf{7 5 - 1 0 0 \%}$ of wound filled & P-value \\
\hline \multirow{3}{*}{ Control group } & Baseline & 16 & 8 & 6 & 0 \\
\cline { 2 - 6 } & 7 days & 14 & 4 & 12 & 0 \\
\cline { 2 - 6 } & 14 days & 7 & 8 & 8 & 7 \\
\hline \multirow{3}{*}{ Study group } & Baseline & 19 & 6 & 5 & 0 \\
\cline { 2 - 6 } & 7 days & 15 & 9 & 6 & 0 \\
\cline { 2 - 6 } & 14 days & 0 & 7 & 6 & 17 \\
\hline
\end{tabular}

Table 4: Comparison of size of ulcer

\begin{tabular}{|c|c|c|c|c|c|}
\hline \multicolumn{2}{|c|}{ Group } & \multicolumn{3}{c|}{ Size of ulcer } & \multirow{3}{*}{ P-value } \\
\cline { 3 - 6 } & $\langle\mathbf{5} \mathbf{~ c m}$ & $\mathbf{6 - 1 0} \mathbf{~ c m}$ & $\mathbf{1 1 - 2 0} \mathbf{~ c m}$ & \\
\hline \multirow{3}{*}{ Control group } & Baseline & 6 & 17 & 7 & \\
\cline { 2 - 5 } & 7 days & 9 & 14 & 7 & \multirow{3}{*}{0.279} \\
\cline { 2 - 5 } & 14 days & 14 & 11 & 5 & \\
\hline \multirow{3}{*}{ Study group } & Baseline & 8 & 13 & 9 & \\
\cline { 2 - 5 } & 7 days & 17 & 8 & 5 & \multirow{3}{*}{0.007} \\
\cline { 2 - 5 } & 14 days & 22 & 6 & 2 & \\
\hline
\end{tabular}

\section{Conclusion}

The goal of this study was to enhance the wound/ulcers to be devoid of necrotic tissue and debris. In individuals with diabetic foot ulcers treated with topical application of phenytoin, this prospective randomised control study indicates better wound healing and sense of well-being than the other classical wound dressing products. Phenytoin promotes wound healing by following mechanisms: Stimulation of fibroblast proliferation, enhancing the formation of granulation tissue, decreasing collagenase activity.

\section{Limitations}

In the future, however, more trials with larger samples are required before topical phenytoin dressing can be applied to the broad spectrum of treatment modalities available for diabetic ulcer management.

\section{References}

1. Gayle R, Benjamin AL, Gary NG. The burden of diabetic foot ulcers. The American Journal of Surgery, 2016.

2. Quari FA, Akbar D, Diabetic foot presentation and treatment, Saudi med J. 2000 May;21(5):443-6.

3. Levin ME. Pathogenesis and general management of foot lesions, 6th edition, 2001, 219-260.

4. Kumar CS, Vasudeva N, Rao DV, Naidu CRSA. Kumar CS, et al. J Clin Orthop Trauma. 2020 Dec 1;13:116-121. DOI: 10.1016/j.jcot.2020.11.019. e-Collection 2021 Feb.

5. Inchingolo $F$, Vermesan $D$, Inchingolo AD, Malcangi G, Santacroce L, Scacco S, et al. Acta Biomed. 2017 Apr 28;88(1):45-48. DOI: 10.23750/abm.v88i1.5794.

6. Bhatia A, Prakash S. Bhatia A, et al. Dermatol Online J. 2004 Jul 15;10(1):5.

7. Pendse S. Understanding diabetic foot. Int J Diabetes Dev Ctries. 2010;30:75-79.

8. Kato T, Okahashi N, Kawai S, Kato T, Inaba H, Morisaki I, et al. Impaired degradation of matrix collagen in human gingival fibroblasts by the antiepileptic drug phenytoin. J Periodontol. 2005;76:941-50.

9. Citron DM, Goldstein EJ, Merriam CV, Lipsky BA, Abramson MA. Bacteriology of moderate-to-severe diabetic foot infections and in vitro activity of antimicrobial agents. J Clin Microbiol. 2007;45:2819-28. 
10. Tascini C, Piaggesi A, Tagliaferri E, Iacopi E, Fondelli S, Tedeschi A, et al. Microbiology at first visit of moderate-to severe diabetic foot infection with antimicrobial activity and a survey of quinolone monotherapy. Diabetes Res Clin Pract, 2011. 